\title{
ETIKA PROFESI SEBAGAI UPAYA PREVENTIF UNTUK MEMINIMALISASI PELANGGARAN HUKUM YANG DILAKUKAN OLEH GURU
}

\author{
Pudji Astuti \\ Prodi Hukum Jurusan PMP-KN \\ Fakultas Ilmu Sosial Universitas Negeri Surabaya \\ Email: toetche60@yahoo.co.id
}

\begin{abstract}
Violation of the law is often done by teachers in performing their duties. Not only breachin the learning process, but often violence against students, particularly in elementary schools. This is very worrying psychological development of students. In fact they are the nation hope. To eliminate such action is necessary to repressive and preventive efforts. Efforts made by the repressive administrative sanctions to criminal sanctions if violations of law have occurred. Preventive efforts are made to implement aTeacher Professional Ethics. Teacher Professional Ethics serves as a quality control and behavior of teachers in performing their duties to ensure customer satisfaction for his services.
\end{abstract}

Key words: professional ethics, preventive efforts.

\begin{abstract}
Abstrak
Pelanggaran hukum sering dilakukan oleh guru dalam melaksanakan tugasnya. Tidak hanya pelanggaran dalam proses pembelajaran, tetapi sering kekerasan terhadap siswa, terutama di sekolah dasar. Hal ini sangat mengkhawatirkan perkembangan psikologis siswa. Pada kenyataannya mereka adalah harapan bangsa. Untuk menghilangkan tindakan tersebut diperlukan untuk upaya represif dan preventif. Upaya yang dilakukan oleh sanksi administratif represif sanksi pidana jika pelanggaran hukum telah terjadi. Upaya pencegahan yang dilakukan untuk menerapkan Etika Profesi. Etika Profesiberfungsi sebagai kontrol kualitas dan perilaku guru dalam melaksanakan tugasnya untuk menjamin kepuasan pelanggan atas jasa-jasanya.
\end{abstract}

Kata kunci: etika profesi, upaya pencegahan.

\section{Latar Belakang}

Tujuan negara untuk mencerdaskan kehidupan bangsa, dituangkan dalam Alinea IV Pembukaan dan Pasal 31 Undang-undang Dasar Negara Republik Indonesia Tahun 1945 (UUD 1945). Sebagai aturan pelaksanaannya, maka legislator mengembangkan instrumen melalui Undangundang Nomor 20 Tahun 2003 tentang Sistem Pendidikan Nasional (UU Sisdiknas) dan Undangundang Nomor 14 Tahun 2005 tentang Guru dan Dosen (UU Guru dan Dosen). Tujuannya demi meningkatkan profesionalitas dan kesejahteraan guru, sebagai upaya preventif dalam mengelimi- nasi pelanggaran hukum yang dilakukan oleh guru. Konsekuensinya, maka pemerintah berkewajiban meningkatkan profesionalitas guru mulai dari sisi akademik hingga memberikan tunjangan profesi dalam rangka peningkatan kesejahteraannya. Ada berbagai strategi yang dilakukan oleh pemerintah. Pertama, meningkatkan jenjang pendidikan guru dengan memberikan beasiswa. Kedua, meningkatkan profesi dengan program sertifikasi guru antara lain melalui jalur Program Latihan Pendidikan Guru (PLPG), dan Pelatihan Profesi Guru (PPG). Melalui program tersebut, kemampuan profesionalitas guru semakin terjamin. Ketiga, 
memberikan tunjangan profesi bagi guru yang telah memperoleh sertifikat pendidik. Sementara itu, sejumlah pemerintah daerah juga memberikan insentif tambahan tunjangan jabatan guru.

Penjaminan atas keprofesionalitasan guru, didasarkan pada UU Sisdiknas, UU Guru dan Dosen, serta Peraturan Pemerintah (PP) Nomor 74 Tahun 2008 tentang Sertifikasi Guru. Selain menjadi landasan penerapan sertifikasi guru, perundangan tersebut memberikan ruang bagi guru untuk mengembangkan organisasi profesi. Melalui organisasi profesi, Kode Etik Guru dapat dilahirkan dan diterapkan, sehingga dapat mengontrol dan menjaga perilaku guru. Tahun 2008, Persatuan Guru Republik Indonesia (PGRI) sebagai organisasi profesi guru berhasil mengembangkan Kode Etik Guru. Namun, sejak di-launching, justru terjadi peristiwa yang menunjukkan ketidakprofesionalitasan guru. Pelanggaran hukum terjadi di bidang akademik, bahwa ada dugaan keterlibatan guru dalam kecurangan Ujian Nasional (UNAS), mulai dari SD Gadel, Surabaya hingga SD Pesanggrahan, Jakarta ${ }^{1}$.

Bentuk lain perilaku guru yang dinilai oleh masyarakat sebagai ketidakprofesionalitasan guru adalah kekerasan kepada siswa pada saat pengajaran di sekolah. Perilaku ini menjadi sangat disoroti tidak saja oleh masyarakat, tetapi juga sejumlah pihak, seperti lembaga perlindungan anak. Kekerasan itu tidak saja berupa fisik, tetapi simbolik, atau kedua-duanya dilakukan secara bersamaan. Di tahun 2012 misalnya, ada kasus kekerasan guru terhadap siswi bernama Siti Maisaroh, 8 tahun, siswi Kelas III SDN 3 Pagi Tugu Utara, Koja, Jakarta. Menurut siswi tersebut, ia dihukum gurunya karena tidak mengerjakan pekerjaan rumah. Meski sudah mengerjakan ulangan, Siti Maisaroh tetap diberi nilai nol, meski jawaban soal itu benar. Guru tersebut menulis angka 'nol' dengan sangat besar di halaman buku anak itu. Pada angka nol yang ditulis, guru menggambar wajah orang dengan dua mata dan hidung mirip angka enam. Selain Siti Maisaroh, Ajeng, temannya juga menjadi korban karena salah mengerjakan pekerjaan rumah. Kepala Ajeng dipukul dengan buku pekerjaan rumah. Bukunya kemudian dirobek-robekdan dilempar. Ketika dikonfirmasi, Kepala Sekolah SDN 23 Pagi, Susiwi Astuti mengatakan, perlakuan keras guru itu masih wajar. "Itu cuma masalah sepele. Kalau enggak mau dimarahi, ya enggak usah sekolah," kata Susiwi pada 9 September 2012².Contoh lain adalah kekerasan yang dilakukan oleh Guru SDN Tulusrejo IV, Kota Malang. Karena tidak mengerjakan tugas, guru tersebut menampar kelima siswanya, salah satunya AY. Selain menampar, ia merobek buku siswa tersebut ${ }^{3}$.

Kekerasan anak di sekolah disadari atau tidak telah menjadi bagian dalam kehidupan sekolah. Ini terbukti dari 1.000 siswa mulai dari jenjang SD sederajat hingga SMA sederajat di sembilan propinsi Indonesia yang disurvei oleh Komisi Perlindungan Anak Indonesia (KPAI), 87,6\% mengaku pernah mengalaminya. Dari jumlah itu, 29,9\% siswa mengaku bahwa pelakunya adalah gurunya sendiri ${ }^{4}$. Bila mengikuti pendapat Jamaluddin Ancok, kekerasan guru terjadi karena beban guru yang tinggi akibat program sertifikasi guru dan tunjangan profesionalitas di satu sisi. ${ }^{5}$ Di sisi lain, sekolah lebih mengedepankan aspek kognitif dalam mendidik anak dan mengabaikan pendidikan budaya dan karakter.

Sementara itu, Federasi Serikat Guru Indonesia (FSGI) menilai kekerasan itu tidak terlepas dari pendekatan behavioristik yang masih dilakukan di Indonesia di satu sisi. Di sisi lain, melalui Kode Etik Guru yang dikembangkan oleh Persatuan Guru Republik Indonesia (PGRI), guru masih diberi ruang untuk melakukan hal tersebut ${ }^{6}$. Peluang tindak kekerasan guru itu ditunjukkan pada pasal 6 ayat (1) huruf f Kode Etik Guru tentang hubungan guru dan peserta didik yang berbunyi"...Guru menjalin hubungan dengan peserta didik yang dilandasi rasa kasih sayang dan menghindarkan diri dari tindak kekerasan fisik yang di luar batas kaidah pendidikan....".

Kompas, 15 Juni 2011, Kronologi Nyontek Massal Di SD Pesanggrahan.

Kompas, 23 September 2012, Siswa SD Negeri 23 Laporkan Kekerasan Oleh Guru.

Kompas, 29 Nopember 2012, Siswa Ditampar Guru Karena Tak Mengumpulkan Tugas.

Kompas, 30 Juli 2012, Kekerasan Di Sekolah Pernah Dialami 87,6 Persen Siswa. Dan ABC Australia, 20 Desember 2012 , Kekerasan Di Sekolah Meningkat, Mendesak KebijakanSekolah Ramah Anak.

5 Jamaludin Ancok, 4-10 Juni 2012, Kekerasan Di Balik Dinding Sekolah, Prioritas.

6 Berita Satu, 27 Januari 2013, FSGI Akui Kekerasan Kerap Terjadi Di Sekolah. 
Dalam pemahaman ini, selama kekerasan itu berada dalam batas kaidah pendidikan, guru boleh melakukannya.

Hubungan antara pelanggaran hukum yang dilakukan guru dan Kode Etik Guru menjadi menarik untuk dikaji. Pelanggaran hukum yang dilakukan guru terekam oleh masyarakat melalui media massa terjadi pada saat sebelum Kode Etik Guru diimplementasikan. Kode Etik Guru mulai diimplementasikan pada tanggal 1 Januari 2013, mengingat Dewan Kehormatan Profesi Guru yang bertugas mensosialisasi, mengimplementasikan dan mengkontrol berlakunya Kode Etik Guru baru terbentuk pada bulan Pebruari 20117 . Konsekuensinya, konflik antara siswa, orangtua dan guru berkaitan dengan pelanggaran hukum yang dilakukan oleh guru dapat diselesaikan dengan cara, pertama penyelesaian di kantor polisi. Kedua melalui jalan perdamaian antara pihak keluarga siswa dan sekolah, yang biasa dilakukan bila pelanggaran hukum dipahami baik oleh orangtua dan pihak sekolah sebagai bagian yang "wajar" dalam proses pendidikan. Ketiga pelanggaran hukum yang dilakukan oleh guru diselesaikan melalui proses hukum bila menyangkut masalah kekerasan yang menghilangkan nyawa dan kesesusilaan.

Upaya represif dalam penyelesaian pelanggaran-pelanggaran hukum di atas sering kali menimbulkan kesalahpahaman di masyarakat, membutuhkan waktu, tenaga dan biaya yang cukup banyak, dapat menimbulkan cap (labeling) yang susah untuk dihilangkan. Adanya cap mengakibatkan pelaku susah diterima dalam kelompok sosialnya, sehingga ia menjadi terkucil dan bersosialisasi dengan kelompok yang juga mendapatkan cap yang sama, hal ini dapat menjadi penyebab timbulnya pelanggaraan hukum baru atau pengulangan. Untuk itu perlu dipikirkan upaya lain yang dapat mengeliminasi pelanggaran hukum yang dilakukan oleh guru tanpa menimbulkan akibat negatif.

Berkaitan dengan Kode Etik Guru yang diterbitkan oleh PGRI dan belum sempat disosialisasikan, karena perangkatnya baru terbentuk pada bulan Pebruari 2011, maka timbul pertanyaan dalam tulisan ini adalah:Apakah Etika Profesi Guru dapat digunakan sebagai upaya preventif dalam mengeliminasi pelanggaran hukum yang dilakukan oleh guru tanpa menimbulkan akibat yang negatif?

\section{Pembahasan}

Pasal 1 angka 1 UU Sisdiknas diatur bahwa pendidikan sebagai : "Usaha sadar dan terencana untuk mewujudkan suasana belajar dan proses pembelajaran agar peserta didik secara aktif dapat mengembangkan potensi dirinya untuk memiliki kekuatan spiritual atau keagamaan, pengendalian diri, kepribadian, kecerdasan, akhlak mulia, serta ketrampilan yang diperlukan dirinya, masyarakat, bangsa dan negara". Karena itu, kebijakan di bidang pendidikan merupakan faktor yang perlu diperhatikan.

Pendidikan sebagai proses pembentukan manusia yang bermoral, berpengetahuan, berkepribadian dan trampil (manusia seutuhnya) dapat ditempuh melalui jalur pendidikan formal, non formal ataupun in formal. Membentuk manusia seutuhnya yang bermoral dan berkepribadian, berarti membina kesehatan jiwa seseorang. Hal ini merupakan salah satu upaya preventif dalam menanggulangi perilaku guru yang melanggar hukum dalam melaksanakan tugasnya. Sesuai pendapat Hoefnagels yang dikutip Barda Nawawi Arief, bahwa: “Pencegahan kejahatan sebenarnya ada pada pribadi manusia itu sendiri". Pada Kongres PBB yang ke-6 ditegaskan bahwa: "Strategi pencegahan kejahatan harus didasarkan pada usaha membangkitkan semangat/jiwa manusia dan usaha memperkuat kembali keyakinan akan kemampuan untuk berbuat baik" . Sehingga melalui proses pendidikan diharapkan pembentukan dan pembinaan kesehatan jiwa masyarakat dapat menjadi faktor anti kriminogen.

Pasal 36 ayat (3) UU Sisdiknas mengatur tentang kurikulum Pendidikan Nasional. Pasal tersebut menekankan bahwa kurikulum yang disusun oleh setiap lembaga pendidikan harus memperhatikan faktor-faktor yang berkaitan dengan pembinaan kesehatan jiwa siswa, seperti faktor peningkatan iman dan takwa, faktor pening-

\footnotetext{
7 Vivanews, 8 Desember 2012, Tingkatkan Mutu Pendidikan, Kode Etik Guru Berlaku Tahun 2013.

8 Barda Nawawi Arief, Bunga Rampai Kebijakan Hukum Pidana, Citra Aditya Bhakti, Bandung, 1996, hlm. 49.

$9 \quad$ Ibid., hlm.55.
} 
katan akhlak mulia, faktor agama, dan nilai-nilai kebangsaan. Faktor-faktor ini sangat dibutuhkan siswa agar dapat mempertahankan dan berbuat sesuai dengan nilai kebaikan dan kebenaran.

Berbagai upaya telah dilakukan untuk meningkatkan pendidikan, namun untuk mencapai apa yang dimaksud Pasal 1 butir 1 UU Sisdiknas, tidaklah mudah, karena keberhasilan Sistem Pendidikan Nasional bergantung pada komponen-komponen pendidikan. Berdasarkan Pasal 1 butir 3 UU Sisdiknas dinyatakan bahwa "Sistem Pendidikan Nasional merupakan keseluruhan komponen pendidikan yang saling terkait secara terpadu untuk mencapai tujuan pendidikan nasional". Jadi bekerjanya Sistem Pendidikan Nasional dalam mencapai tujuan pendidikan sangat bergantung pada komponen-komponen pendidikan yang saling terkait satu sama lain, seperti lembaga pendidikan, pemerintah, pendidik, siswa, sarana dan prasarana, dan masih banyak lagi. Selama proses pendidikan tidak menutup kemungkinan terjadinya pelanggaran hukum yang dilakukan oleh komponen-komponen pendidikan, seperti lembaga pendidikan, siswa, pihak ke tiga, bahkan dari pendidik sendiri, maka tujuan pendidikan tidak akan tercapai. Sehingga perlu adanya penanganan secara serius dalam menanggulangi pelanggaran-pelanggaran hukum di bidang pendidikan, baik secara represif maupun preventif.

Upaya represif merupakan cara yang digunakan bila telah terjadi pelanggaran hukum yang dilakukan oleh komponen-komponen di bidang pendidikan dengan tujuan menakut-nakuti ataupun membuat jera pelakunya sehingga tidak akan mengulangi perbuatannya lagi. Pendapat John Kaplan yang dikutip Muladi dan Barda Nawawi Arief disebutkan bahwa : "tujuan pemidanaan yang lain adalah :

a) untuk menghindari balas dendam (Avoidance of blood feuds)

b) adanya pengaruh yang bersifat mendidik (the educational effect)

c) mempunyai fungsi memelihara perdamaian (the peace-keeping function) ${ }^{\prime} .{ }^{10}$

Namun demikian upaya represif ini dapat berjalan efektif jika dalam kebijakan penggunaannya melalui pendekatan humanitis, mengingat pelanggaran hukum itu sendiri merupakan gejala kemanusiaan.

Ted Honderich berpendapat suatu pidana dapat disebut sebagai alat pencegah yang ekonomis (economical deterrents) apabila dipenuhi syarat-syarat sebagai berikut :

a) pidana itu sungguh-sungguh mencegah.

b) pidana itu tidak menyebabkan timbulnya keadaan yang lebih berbahaya atau merugikan daripada yang akan terjadi apabila pidana itu tidak dikenakan atau memperhatikan akibatnya.

c) tidak ada pidana lain yang dapat mencegah secara efeketif dengan bahaya/kerugian yang lebih kecil. ${ }^{11}$

Jika dilihat dari pendapat di atas, maka penggunaan upaya represif dalam menanggulangi pelanggaran hukum memerlukan persyaratanpersyaratan yang harus diperhatikan dalam penerapannya. Karena itu dalam menanggulangi pelanggaran hukum yang dilakukan komponenkomponen pendidikan juga dapat diintegrasikan dengan penggunaan upaya preventif.

Upaya preventif merupakan upaya penanggulangan pelanggaran hukum yang dilakukan oleh komponen-komponen di bidang pendidikan sebelum pelanggaran itu terjadi. Jadi upaya preventif bertujuan untuk mencegah terjadinya pelanggaran hukum di bidang pendidikan yang mempunyai sasaran utama yaitu menangani faktor-faktor kondusif penyebab terjadinya pelanggaran. Baik faktor-faktor yang berpusat pada permasalahan atau kondisi sosial yang secara langsung maupun tidak langsung dapat menimbulkan pelanggaran hukum di bidang pendidikan. Seperti faktor lingkungan, faktor keluarga, keadaan ekonomi, pergaulan sosial, agama yang di lihat dari segi siswa, pendidik maupun dari lembaganya serta hal-hal lain yang dapat mendukung terjadinya pelanggaran hukum di bidang pendidikan.

Upaya penanggulangan pelanggaran hukum yang dilakukan oleh guru di bidang pendidikan

10 Muladi dan Barda Nawawi Arief, Teori-teori dan Kebijakan Pidana, Alumni, Bandung, 1984, hlm. 20.

11 Ibid., hlm. 165. 
melalui upaya preventif juga diatur di dalam UU Sisdiknas dan UU Guru dan Dosen. Untuk menanggulangi faktor ekonomi misalnya digunakan program pemberian tunjangan profesional. Program ini wajib diikuti oleh guru melalui program Sertifikasi Guru, sebagaimana diatur Pasal 8 sampai dengan Pasal 13 UU Sisdiknas. Pasal-pasal ini mempunyai tujuan preventif yaitu untuk menghilangkan penyebab terjadinya pelanggaran hukum yang dilakukan oleh guru karena faktor perekonomian. Dipertegas lagi dengan Pasal 42 ayat (1) UU Sisdiknas disebutkan : "Pendidik harus memiliki kualifikasi minimum dan sertifikasi sesuai dengan jenjang kewenangan mengajar, sehat jasmani dan rohani, serta memiliki kemampuan untuk mewujudkan tujuan pendidikan nasional". Jelas UU Sisdiknas juga mengatur penanggulangan pelanggaran hukum yang dilakukan oleh guru di bidang pendidikan dengan jalan menghilangkan penyebabnya yaitu faktor ekonominya.

Di Bidang pendidikan, komponen guru merupakan komponen yang utama dalam proses pendidikan, mengingat guru mempunyai kedudukan dan peran yang paling dominan dalam pelaksanaan pendidikan dan pengajaran.Pendidik sebagai salah satu pilar pelaksana pembangunan dan pembinaan mental bangsa dituntut memiliki integritas dan kemampuan profesional yang tinggi agar mampu melaksanakan darma baktinya dalam mencerdaskan dan mensejahterakan kehidupan bangsa. Dapat dibayangkan bagaimana masa depan bangsa dan negara seandainya terjadi pelanggaran hukum yang dilakukan guru, mengingat guru mempunyai kewajiban dan peran yang sangat penting dalam mengembangkan bukan hanya ketrampilan anak bangsa tetapi juga pengetahuan, kepribadian, dan moralnya. Pendidik mempunyai kewajiban untuk memberi teladan bagi siswanya. Pasal 40 (2) butir c UU Sisdiknas mengatur mengenai kewajiban guru yang berbunyi : "Memberi teladan dan menjaga nama baik lembaga, profesi dan kedudukan sesuai dengan kepercayaan yang diberikan kepadanya". Dalam rangka mengeliminasi terjadinya pelanggaran-pelanggaran hukum di bidang pendidikan yang dilakukan oleh guru, maka dikeluarkanlah UU Nomor 14 Tahun 2005 tentang Guru dan Dosen yang berisi tentang pengaturan dan pengembangan fungsi guru dan dosen sebagai profesi yang bermartabat.

Guru sebagai tenaga profesional memiliki kode etik sebagai upaya menciptakan dan menjaga ketertiban hidup dalam masyarakat ketika hukum tidak berfungsi secara efektif. Etika profesi Guru dapat digunakan sebagai salah satu sarana preventif dalam mengeliminasi terjadinya pelanggaran-pelanggaran hukum di bidang pendidikan.

Profesi menurut Soetandyo mempunyai arti: "suatu kegiatan kerja, khusus yang mempunyai tiga kriteria ciri yang secara mutlak harus ada, ciri tersebut adalah :

a) Adanya itikad pekerjaan yang dinyatakan dalam suatu ikrar atau sumpah di muka umum untuk melakukan kegiatan yang diakui dan dijunjung tinggi oleh masyarakat sebagai suatu kebajikan, sehingga tidak mengharapkan imbalan atas jasanya;

b) Penguasaan atas suatu kemahiran teknis bermutu tinggi yang dapat digunakan untuk merealisasikan kebajikan tersebut dengan baik;

c) Adanya kesediaan para profesional untuk tunduk pada kode etik yang disepakati bersama dalam organisasi profesional secara suka rela dan ikhlas, sebagai kontrol terhadap profesionalismenya. " ${ }^{2}$

Menurut G. Millerson dalam bukunya Ignatius Ridwan Widyadharma mengatakan bahwa "ciri dari profesional adalah :

a) Mempunyai ketrampilan yang berdasarkan pada pengetahuan teoritis;

b) Penyediaan latihan dan pendidikan;

c) Pengujian kemampuan anggota;

d) Organisasi;

e) Kepatuhan kepada suatu peraturan manprofesional;

f) Jasa/pelayanan yang sifatnya altruistik. ${ }^{13}$

Pasal 1 angka 4 UU Nomor 14 Tahun 2005 tentang Guru dan Dosen disebutkan : "Profesional adalah pekerjaan atau kegiatan yang dilakukan

12 Soetandyo Wignyosubroto, Hukum dalam Masyarakat Perkembangan dan Masalah Sebuah Pengantar Ke Arah Kajian Sosiologi Hukum, Bayu Media Publishing, Malang, 2007, hlm. 212-213.

13 Ignatius Ridwan Widyadharma, Etika Profesi Hukum, Badan Penerbit Universitas Diponegoro, Semarang,1996,hlm. 39. 
oleh seseorang dan menjadi sumber penghasilan kehidupan yang memerlukan keahlian, kemahiran, atau kecakapan yang memenuhi standar mutu atau norma tertentu serta memerlukan pendidikan profesi". Berdasarkan ciri-ciri tersebut, maka tenaga profesional adalah tenaga yang mempunyai keahlian dan bekerja demi kebajikan dan kepentingan umum serta harus tunduk pada etika profesi yang disusun oleh organisasi profesi itu sendiri sebagai kontrol atas kualitas pelayanannya pada masyarakat.

Kontrol atas keahlian dan perilaku etis kaum profesional pertama-tama berasal dari organisasi profesi itu sendiri yang pelaksanaannya diawasi oleh suatu Dewan Kehormatan Profesi yang dibentuk khusus untuk menegakkan berlakunya etika profesi. Jelas di sini bahwa kalangan profesi harus mengutamakan kebajikan dalam melaksanakan profesinya, dan untuk menjalankan kebajikan tersebut perlu ditunjang dengan keahlian teknisnya, sedangkan etika profesi sebagai kontrolnya.

Guru merupakan tenaga pendidik, dinyatakan sebagai tenaga profesional berdasarkan UU Guru dan Dosen, sehingga guru juga terikat dengan etika profesinya. Etika profesi yang berlaku bagi guru disusun oleh organisasi profesi guru PGRI yang pelaksanaannya diawasi oleh Dewan Kehormatan Profesi Guru yang dibentuk oleh PGRI sendiri. Berdasarkan Pasal 41 UU Guru dan Dosen, maka guru-guru diwajibkan membentuk organisasi profesi dan setiap guru wajib menjadi anggota organisasi profesi tersebut. Upaya ini merupakan langkah preventif untuk mengeliminasi faktorfaktor penyebab terjadinya pelanggaran-pelanggaran hukum di bidang pendidikan yang dilakukan oleh guru, sehingga dapat mencegah terjadinya tindak pidana di bidang pendidikan.

Kode Etik Guru yang disusun oleh PGRI telah diikrarkan dalam Kongres PGRI XX Tahun 2008 di Palembang yang bertujuan dan bertekad menjadikan guru sebagai pendidik yang andal untuk mewujudkan tujuan pendidikan nasional yaitu mengembangkan potensi siswa untuk menjadi manusia seutuhnya. Guru tidak hanya dituntut andal dalam bidang keilmuannya, tetapi dituntut memiliki kompetensi paedagogik, kompetensi kepribadian, kompetensi sosial, dan kompetensi profesional. Artinya guru dituntut untuk bertanggung jawab mengantarkan siswanya mencapai kedewasaan sebagai calon pemimpin bangsa pada semua bidang kehidupan. Guru harus dapat menjadi tauladan, menjadi insan yang dapat ditiru baik dalam kehidupan bermasyarakat, berbangsa ataupun bernegara

Kode Etik Guru yang disepakati oleh guruguru untuk dijadikan pedoman dalam berperilaku saat menjalankan tugasnya sebagai pendidik, anggota masyarakat dan warga negara bersumber pada berbagai nilai. Pasal 5 Kode Etik Guru yang disusun oleh PGRI menyebutkan bahwa

"Kode Etik Guru Indonesia bersumber dari :

a) Nilai-nilai agama dan Pancasila

b) Nilai-nilai kompetensi paedagogik, kompetensi kepribadian, kompetensi sosial, dan kompetensi profesional.

c) Nilai-nilai jati diri, harkat dan martabat manusia yang meliputi perkembangan kesehatan jasmaniah, emosional, intelektual, sosial, dan spiritual.“

Bunyi Pasal 5 Kode Etik Guru ini benarbenar dapat digunakan sebagai upaya mencegah terjadinya pelanggaran hukum di bidang pendidikan yang dilakukan oleh guru, karena dapat menjaga kualitas dan perilaku guru dalam menjalankan profesinya. Upaya ini dapat terealisasi jika Kode Etik Guru benar-benar diimplementasikan, dijaga dan ditaati. Artinya jika terjadi pelanggaran atas Kode Etik Guru, maka sanksi yang diancamkan harus benar-benar dijatuhkan oleh Dewan Kehormatan Profesi Guru Indonesia pada guru yang melanggarnya.

Kenyataannya Dewan Kehormatan Profesi Guru Indonesia baru dibentuk tiga tahun setelah disepakatinya Kode Etik Guru oleh PGRI, tepatnya pada bulan Pebruari Tahun 2011. Ini berarti Kode Etik Guru selama ini belum diimplementasikan, karena perangkat kelengkapan yang bertugas menegakkan Etika Profesi Guru tersebut baru terbentuk.

Berdasarkan Pasal 9 Kode Etik Guru, yang berwenang mensosialisasikan, mengimplementasikan, mengkontrol dan yang memberikan sanksi bagi guru yang melanggar Kode Etik Guru adalah Dewan Kehormatan Profesi Guru Indonesia yang dibentuk oleh PGRI sendiri. Selain itu Dewan Kehormatan Profesi Guru Indonesia mempunyai tugas memberikan saran, pendapat, pertimbangan, penilaian, penegakan dan sanksi 
pelanggaran disiplin organisasi dan Etika Profesi Guru. Dibentuknya Dewan Kehormatan Profesi Guru Indonesia ini diharapkan dapat segera menjalankan tugasnya dengan sebaik-baiknya, sehingga dapat mencegah terjadinya pelanggaran hukum yang dilakukan oleh guru di bidang pendidikan sebagaimana tujuan dibentuknya Organisasi Profesi Guru.

Berdasarkan UU Guru dan Dosen, guru dalam menjalankan profesinya terikat dengan kontrak sosial yang berupa etika profesi. Etika Profesi Guru menuntut guru dalam melakukan tugas harus sesuai dengan profesinya sebagai pendidik yang dilandasi dengan filosofi pendidikan yaitu " menjadikan baik siswa, baik dari segi moral, pengetahuan dan ketrampilannya atau menjadikan siswa menjadi manusia seutuhnya". Kontrak sosial antara guru dengan masyarakat telah memberi kewenangan kepada para guru untuk mengatur diri mereka sendiri, sebaliknya guru harus memberikan pelayanan yang bermutu kepada masyarakat. Pada profesi guru, masyarakat melalui Organisasi Profesi Guru (seperti PGRI) memberi kewenangan untuk menyusun etika profesi yang dapat digunakan oleh guru sebagai pedoman melaksanakan tugasnya dengan layak untuk memproteksi masyarakat.

Pengawasan terhadap guru dalam melaksanakan tugasnya dilakukan oleh Organisasi Profesi Guru melalui Dewan Kehormatan yang dibentuk oleh Organisasi profesional itu sendiri. Jika Organisasi Profesi Guru membiarkan guru bekerja tidak sesuai disiplin profesi serta tidak melandaskan pada Etika Profesi Guru maka akan muncul ketidakpercayaan masyarakat kepada profesi yang selama ini dianggap sebagai profesi luhur. Tugas Organisasi Profesi Guru melakukan penegakkan Etika Profesi bagi guru yang diduga melakukan pelanggaran etika profesi yang menyimpang dari standart profesinya sehingga membahayakan perkembangan siswanya. Organisasi Profesi Guru juga bertugas menjamin kelayakan guru dalam melaksanakan tugasnya. Kelayakan yang dimaksud di sini adalah kelayakan dari segi pengetahuan, ketrampilan maupun perilakunya.

Penegakkan disiplin profesi dimaksudkan untuk menilai 3 aspek yaitu kinerja paedagogis, perilaku profesional dan kelayakan fisik atau mental pendidik. Dalam penilaian kinerja paedagogis digunakan parameter pelaksanaan pendidikan sesuai dengan standar, yaitu visi, misi, prosedur operasional dan lain-lain Untuk menilai perilaku profesional digunakan pedoman perilaku profesional yang disusun oleh organisasi profesi seperti PGRI atau IGI (Ikatan Guru Indonesia). Jika ditemukan penyimpangan kinerja ataupun perilaku yang serius, maka Dewan Kehormatan Organisasi Profesi Guru Indonesia dapat menjatuhkan sanksi disiplin yang diharapkan dapat memberi efek pencegahan pengulangan dan pelanggaran hukum.

Organisasi profesi Guru di samping berfungsi sebagai pengontrol perilaku guru dalam melaksanakan profesinya, juga berkewajiban memberikan perlindungan terhadap harkat dan martabat guru dari segala ancaman yang dapat melecehkan kedudukan guru sebagai tenaga pendidik (profesional). Ini tertuang dalam Anggaran Dasar Organisasi Profesi Guru PGRI dalam Pembukaannya alinea 7 yang berbunyi

"Guru sebagai salah satu pilar pelaksana pembangunan pendidikan dituntut memiliki integritas dan kemampuan profesional yang tinggi agar mampu melaksanakan darma baktinya dalam mencerdaskan kehidupan bangsa. PGRI bertujuan dan berupaya membina, mempertahankan, dan meningkatkan harkat dan martabat guru melalui peningkatan kemampuan profesionalnya dan kesejahteraan guru beserta keluarganya".

Pembukaan Anggaran Dasar Organisasi Profesi Guru PGRI, menunjukkan peranan organisasi profesi ini sangat penting dalam menunjang pelaksanaan pendidikan dan dalam mencegah pelanggaran hukum di bidang pendidikan, mengingat fungsi organisasi profesi lebih mengarah pada fungsi pencegahan terjadinya pelanggaran Hukum di bidang pendidikan.

Kenyataannya organisasi profesi guru (PGRI) belum mempunyai Dewan Kehormatan Profesi Guru. Dewan Kehormatan Profesi Guru baru dibentuk tanggal 12 Pebruari 2011. Pembentukan Dewan Kehormatan Profesi Guru dilatarbelakangi adanya UU Guru dan Dosen yang menetapkan bahwa pekerjaan guru merupakan pekerjaan profesional, sehingga harus tunduk pada etika profesi yang penegakkannya merupakan tanggung jawab Dewan Kehormatan Organisasi Profesi 
Guru. Selain itu Pembentukan Dewan Kehormatan Profesi Guru merupakan realisasi dari keputusan Kongres PGRI ke XX pada bulan Juli 2008 yang dilaksanakan di Palembang. Karena Dewan Kehormatan Profesi Guru baru terbentuk, maka saat ini masih dalam tahap persiapan untuk melaksanakan apa yang menjadi tugasnya sesuai dengan isi Anggaran Dasar dan Anggaran Rumah Tangganya, sehingga belum dapat berfungsi seperti apa yang diharapkan.

Sebenarnya PGRI sudah cukup lama menyusun Etika Profesi Guru, namun belum tersosialisasi dengan baik, sehingga sebagian besar anggota belum mengetahuinya. Selama ini PGRI lebih banyak melakukan kegiatan yang berkaitan dengan peningkatan kualitas organisasinya dan kualitas guru dalam bidang keilmuan dan ketrampilannya saja, belum menyentuh bidang moralnya.

Upaya preventif dalam mengeliminasi pelanggaran hukum di bidang pendidikan sebagaimana digambarkan di atas, merupakan sarana yang efisien bila dibandingkan dengan upaya represif, karena upaya preventif lebih bersifat mencegah dan tidak menimbulkan cap (labeling) yang berakibat buruk bagi pelaku. Selain itu upaya preventif bertujuan untuk menghilangkan faktor-faktor yang dapat menimbulkan pelanggaran hukum lebih dapat menghemat biaya, waktu, tenaga, dan dapat mengurangi dampak adanya pemidanaan. Lebih-lebih jika diperhatikan pendapat Nigel Walker bahwa :

"Hukum pidana tidak boleh digunakan untuk:

1. tujuan pembalasan;

2. terhadap perbuatan yang tidak menimbulkan korban dan/kerugian;

3. bila mana masih ada sarana lain yang lebih efektifdan dengan kerugian yang lebih sedikit dalam menanggulangi perbuatan yang dianggap tercela;

4. bila dampak negatif pidana lebih besar daripada tindak pidana;

5. apabila tidak mendapat dukungan publik yang kuat;

6. apabila sudah diperhitungkan tidak akan berhasil atau tidak akan dapat dilaksanakan. ${ }^{\text {" }}{ }^{14}$

Hukum pidana yang berfungsi sebagai ultimum remidium, meletakkan sanksi pidana sebagai sanksi terakhir yang diancamkan. Namun demikian jika upaya preventifl ini tidak ditangani secara serius, maka dapat mengakibatkan terjadinya pelanggaran hukum yang lebih serius. Untuk itu perlu adanya keterpaduan antara pelaksanaan upaya preventif dan represif.

Keunggulan upaya preventif dalam mengeliminasi pelanggaran hukum di bidang pendidikan ini, maka perlu mengaktifkan Organisasi Profesi Guru dalam menjalankan tugasnya demi peningkatan kualitas guru, baik dari segi paedagogis, pengetahuan maupun ketrampilannya. Organisasi Profesi Guru berperan melakukan pencegahan agar tidak terjadi pelanggaran hukum di bidang pendidikan yang dilakukan oleh guru. Untuk mencapai tujuan ini, maka Dewan Kehormatan Profesi Guru harus segera melaksanakan tugasnya mensosialisasikan dan mengimplentasikan dan menegakkan Etika Profesi Guru yang tercantum dalam Anggaran Dasar dan Anggaran Rumah Tangganya, sehingga guru dapat terjaga harkat dan martabatnya.

UU Guru dan Dosen sebagai UU yang mendasari diwajibkannya setiap guru menjadi anggota Organisasi Profesi Guru diundangkan tahun 2005, dan organisasi guru PGRI telah berdiri mulai tahun 1945. Namun demikian PGRI sebagai Organisasi Profesi Guru belum mempunyai Dewan Kehormatan, dan baru enam tahun setelah UU Guru dan Dosen disahkan dibentuklah Dewan Kehormatan Profesi Guru Indonesia oleh PGRI. Harapan masyarakat Dewan Kehormatan Organisasi Profesi ini dapat segera berkiprah.

\section{Kesimpulan}

Pelanggaran hukum yang dilakukan oleh guru dapat dieliminiasi melalui upaya preventif, yaitu dengan menerapkan Etika Profesi Guru yang disusun oleh Organisasi Profesi Guru sesuai dengan amanat UU Sisdiknas dan UU Guru dan Dosen. Upaya preventif ini lebih efektif dan efisiensi jika dibandingkan dengan upaya represif, karena mencegah lebih baik dari pada mengobati,

14 Didik Endro Purwoleksono, Pidato Pengukuhan Guru Besar "Pengaturan Sanksi Pidana Dalam Ketentuan Undang-undang", Universitas Airlangga, Surabaya, 2008, hlm.13. 
mengobati memerlukan tenaga, waktu, dan biaya yang besar serta memulihkan keadaan seperti semula lebih sulit dari pada mencegahnya. Namun demikian jika upaya preventif ini tidak dilakukan dengan serius dan tanpa diintegrasikan dengan upaya represif, maka akibatnya akan menjadi lebih buruk, karena itu pelaksanaan upaya preventif dan represif harus dilaksanakan secara terintegrsi.

Sosialisasi, implementasi dan pengawasan Etika Profesi Guru menjadi tanggung jawab Dewan Kehormatan Profesi Guru Indonesia yang telah terbentuk pada bulan Pebruari tahun 2011, Untuk itu Dewan Kehormatan Profesi Guru Indonesia harus bekerja keras melaksanakan perannya sebagai lembaga yang bertanggung jawab dalam upaya pencegahan terjadinya pelanggaran hukum yang dilakukan guru dalam melaksanakan tugas mulianya.

Pentingnya Etika Profesi Guru dalam mengeliminasi pelanggaran hukum yang dilakukan oleh guru, maka masyarakat sebagai konsumen harus ikut berperan sebagai kontrol pelaksanaan Etika Profesi Guru. Kontrol tersebut dapat dilakukan melalui pengawasan kerja Dewan Kehormatan Profesi Guru Indonesia dan memberikan penilaian kualitas serta perilaku guru dalam menjalankan tugas mulianya apakah masih melanggar hukum atau tidak.

\section{DAFTAR PUSTAKA}

\section{Buku}

Barda Nawawi Arief, 1996, Bunga Rampai Kebijakan Hukum Pidana, Citra Aditya Bhakti, Bandung.

Didik Endro Purwoleksono, 2008, Pidato Pengukuhan Guru Besar "Pengaturan Sanksi Pidana Dalam Ketentuan Undangundang", Universitas Airlangga, Surabaya.

Ignatius Ridwan Widyadharma, 1996, Etika Profesi Hukum, Badan Penerbit Universitas Diponegoro, Semarang.

Muladi dan Barda Nawawi Arief, 1984, Teoriteori dan Kebijakan Pidana, Alumni, Bandung.

Soetandyo Wignyosubroto, 2007, Hukum dalam Masyarakat Perkembangan dan Masalah Sebuah Pengantar Ke Arah Kajian Sosiologi Hukum, Bayu Media Publishing, Malang.

\section{Artikel}

ABC Australia, 20 Desember 2012, Kekerasan Di Sekolah Meningkat, Mendesak Kebijakan Sekolah Ramah Anak.
Berita Satu, 27 Januari 2013, FSGI Akui Kekerasan Kerap Terjadi Di Sekolah.

Jamaludin Ancok, 4-10 Juni 2012, Kekerasan Di Balik Dinding Sekolah, Prioritas.

Kompas, 15 Juni 2011, Kronologi Nyontek Massal Di SD Pesanggrahan.

Kompas, 23 September 2012, Siswa SD Negeri 23 Laporkan Kekerasan Oleh Guru.

Kompas, 29 Nopember 2012, Siswa Ditampar Guru Karena Tak Mengumpulkan Tugas.

Kompas, 30 Juli 2012, Kekerasan Di Sekolah Pernah Dialami 87,6 Persen Siswa.

Vivanews, 8 Desember 2012, Tingkatkan Mutu Pendidikan, Kode Etik Guru Berlaku Tahun 2013.

\section{Peraturan Perundang-undangan}

Undang-undang Nomor 20 Tahun 2003 tentang Sistem Pendidikan Nasional.

Undang-undang Nomor 14 Tahun 2005 tentang Guru dan Dosen.

Peraturan Pemerintah Nomor 74 Tahun 2008 tentang Sertifikasi Guru. 